\title{
LAYANAN KONSELING KETERAMPILAN HIDUP DALAM PROGRAM PENDIDIKAN LIFESKILLS DI PANTI SOSIAL BINA REMAJA DAN KARYA WANITA "MAJAR TABELA" PALANGKA RAYA
}

\author{
(Counseling Lifeskills Service in Lifeskills Educational Program \\ in Social House of "Bina Remaja dan Karya Wanita Majar Tabela"Palangka Raya)
}

\author{
Asep Solikin $^{1)}$, Endang Sri Suyati ${ }^{2)}$ dan Fahruddin Arfianto $^{3)}$ \\ ${ }^{1)}$ Program Studi Bimbingan dan Konseling Fakultas Keguruan dan IImu Pendidikan \\ ${ }^{2)}$ Program Studi Pendidikan Ekonomi Fakultas Keguruan dan IImu Pendidikan \\ ${ }^{3)}$ Program Studi Agroteknologi Fakultas Pertanian dan Kehutanan \\ Universitas Muhammadiyah Palangkaraya \\ JI. RTA Milono Km.1,5 Palangka Raya, Kalimantan Tengah 73111 \\ e-mail : asep.solikin@yahoo.com \\ endangsuyati@yahoo.co.id \\ fahruddin237@gmail.com
}

\begin{abstract}
Lifeskills counseling attempts to help clients gain strength and eliminate the weakness of their thinking and acting skills; and gain an understanding of the language of skills, namely the ability to think and analyze their behavior in the form of skills.

The purpose of this community service is to give lifeskill counseling services intensively to the participants in the program through the implementation of lifeskill counseling activities in the lifeskills program at the Social House of Bina Remaja dan Karya Wanita (PSBRKW) "Majar Tabela" Palangka Raya of Central Kalimantan Province.

Implementation of lifeskill counseling services truely has a strong impact on the anchoring process for participants who are participating in the program so that the participants have the ability to understand the most useful affective values of their lives after leaving the program: first, they understandthe others; Second, they are be able to anticipate, recognize, and strive to meet the needs of friends around them; Third, they are be able to feel the needs of others' development and try to increase their abilities; Fourth, they are be able to open opportunities through association with various people and able to overcome the problem of difference.
\end{abstract}

Keywords: counseling, life skills

\begin{abstract}
Abstrak
Konseling keterampilan hidup berusaha membantu klien memperoleh kekuatan dan menghilangkan kelemahan keterampilan berpikir dan bertindak; dan memperoleh pemahaman tentang bahasa keterampilan, yaitu kecakapan memikirkan dan menganalisis perilakunya dalam bentuk keterampilan.

Tujuan kegiatan pengabdian kepada masyarakat ini adalah memberikan layanan konseling keterampilan hidup secara intensif kepada para peserta program melalui pelaksanaan kegiatan konseling keterampilan hidup pada program lifeskills di Panti Sosial Bina Remaja dan Karya Wanita (PSBRKW) "Majar Tabela" Palangka Raya Provinsi Kalimantan Tengah.

Pelaksanaan layanan konseling keterampilan hidup sejatinya memberikan dampak kuat pada proses penjangkaran bagi peserta yag mengikuti program ini sehingga peserta memiliki kemampuan memahami nilai-nilai afektif yang sangat berguna pada kehidupan mereka setelah keluar dari program ini yaitu: pertama, memahami orang lain; kedua, mampu mengantisipasi, mengenali, dan berusaha memenuhi kebutuhan teman-teman sekitarnya; ketiga, mampu merasakan kebutuhan perkembangan orang lain dan berusaha menumbuhkan kemampuan mereka; keempat, mampu menumbuhkan peluang melalui pergaulan dengan bermacam-macam orang dan mampu mengatasi masalah perbedaan.
\end{abstract}

Kata kunci : konseling, keterampilan hidup 


\section{PENDAHULUAN}

\section{Analisis Situasi}

Manusia adalah mahluk belajar yang berarti bahwa manusia sepanjang hidupnya selalu belajar. Filsuf yang hidup ribuan tahun yang silam telah mengemukakan pemikiran dengan mengatakan bahwa pendidikan mengarahkan seseorang menentukan kehidupan masa depannya "the direction in which education starts a man will determine his future life" (Plato dalam Cohn, 1997: 27) disamping itu Aristoteles juga dalam Cohn (1997:2) mengemukakan betapa pentingnya pendidikan dengan pernyataannya sebagai berikut Educated men are as such superior to uneducated men as the living are to the dead - orang berpendidikan adalah jauh lebih unggul menjalani kehidupannya menuju kematian.

Pembangunan pendidikan yang saat ini dilaksanakan merupakan wujud dari rasa tanggung jawab serta implementasi untuk terwujudnya cita-cita para pendiri negara dimaksud yaitu "mencerdaskan kehidupan bangsa". Menjadikan bangsa Indonesia yang memiliki kecerdasan dalam arti tunduk dan berbakti kepada Tuhan Yang Maha Esa, berkomunikasi secara efektif, cerdas untuk peduli dan mengangkat derajat sesama, cerdas dan jujur, cerdas untuk menghindari anarkisme, cerdas untuk mengelola sumberdaya manusia dan alam agar bisa dirasakan manfaatnya oleh suluruh bangsa (Soedijarto, 2003).

Rencana Strategis Kementerian Pendidikan Nasional (Renstra) 2010-2014 dibuat dalam rangka mempersiapkan terwujudnya visi Kementerian Pendidikan Nasional tahun 2025 yaitu menghasilkan insan Indonesia cerdas dan kompetitif (insan kamil/insan paripurna). Rencana Strategis Kementerian Pendidikan Nasional 20102014 mengacu pada visi Rencana Pembangunan Jangka Menengah Nasional (RPJMN) 2010-2014 yaitu Indonesia yang sejahtera, demokratis, dan berkeadilan. Arahan Presiden untuk memperhatikan aspek change and continuity, debottlenecking, dan enhancement (Rencana Strategis Kementerian Pendidikan Nasional 20102014). Kebijakan pemerintah pusat ini diimplementasikan oleh Pemerintah Provinsi Kalimantan Tengah dengan program Kalimantan Tengah Harati. Program ini dilaksanakan di seluruh Kabupaten yang berjumlah 13 (tiga belas) dan 1 (satu) Kota.

Seiring dengan perhatian terhadap pentingnya pendidikan, Visi Gubernur Kalimantan Tengah diarahkan pada meneruskan dan menuntaskan pembangunan Kalimantan Tengah agar rakyat lebih sejahtera dan bermartabat demi kejayaan Negara Kesatuan Republik Indonesia. Misi ke 2 (dua) Gubernur Kalimantan Tengah adalah menciptakan pendidikan berkualitas dan terakses serta merata. Pendidikan yang berkualitas berarti pendidikan yang diselenggarakan sesuai dengan standar nasional pendidikan. Sedangkan terakses adalah mampu dijangkau oleh semua orang yang berkeinginan untuk belajar. Pendidikan yang merata dalam arti bahwa semua warga Negara memiliki kesempatan yang sama untuk meningkatkan pengetahuannya melalui pendidikan. Melalui pendidikan maka martabat bangsa Indonesia akan menjadi lebih baik karena melalui pendidikan seseorang akan terlihat nilai tambahnya dalam kehidupan bersama. Pendidikan menurut Undang-Undang Nomor 20 
tahun 2003 tentang Sistem Pendidikan Nasional terdiri dari pendidikan formal, informal dan nonformal.

Meskipun pemerintah melalui kebijakan wajib belajar 9 (Sembilan) tahun sebagaimana UU No. 20 Tahun 2003 pasal 34 Ayat (3) yang menyebutkan bahwa wajib belajar merupakan tanggung jawab negara yang diselenggarakan oleh lembaga pendidikan pemerintah, pemerintah daerah dan masyarakat. Paradigma wajib belajar pendidikan dasar sembilan tahun harus diartikan sebagai hak belajar pendidikan dasar sembilan tahun. Dengan demikian akan menjamin kepastian bagi semua warga negara untuk memperoleh pendidikan minimal sampai lulus Sekolah Menengah Pertama. Meskipun pada kenyataannya pada beberapa kabupaten/kota telah memberlakukan kebijakan wajib belajar sampai 12 tahun yang artinya minimal lulus pendidikan Sekolah Menengah Atas.

Demikian juga para pendiri Republik Indonesia "founding fathers" pada 67 tahun silam mampu berfikir menembus waktu dengan menganggap bahwa pendidikan sangat berpengaruh baik bagi masyarakat Indonesia secara individu maupun dalam kehidupan bernegara. Sampai saat ini pendidikan masih harus dibanggun karena di provinsi Kalimantan berdasarkan data Badan Pusat Statistik tahun 2011 masih terdapat 6,33\% buta huruf dan sebanyak 23,60\% tidak tamat Sekolah Dasar. Sedangkan penduduk dengan latar belakang pendidikan D-1 sampai dengan S-3 baru mencapai $5,21 \%$. Dengan demikian perhatian terhadap pendidikan merupakan hal yang sangat mendesak.Pendidikan merupakan hak asasi setiap warga negara Indonesia dan untuk itu setiap warga negara Indonesia berhak memperoleh pendidikan yang bermutu sesuai dengan minat dan bakat yang dimilikinya tanpa memandang status sosial, status ekonomi, suku, etnis, agama, dan gender. Pemerataan akses dan meningkatan mutu pendidikan akan membuat warga negara Indonesia memiliki kecakapan hidup (life skills) sehingga mendorong tegaknya pembangunan manusia seutuhnya serta masyarakat madani dan modern yang dijiwai nilainilai Pancasila, sebagaimana diamanatkan dalam UU No 20 Tahun 2003 tentang Sistem Pendidikan Nasional.

Menurut data Badan Pusat Statitik provinsi Kalimantan Tengah tahun 2011 angka kemiskinan mencapai $6,64 \%$ atau 150.021 orang. Dalam mengukur tingkat kemiskinan tersebut digunakan pendekatan kebutuhan dasar (basic needs approach) dalam arti kemiskinan dipandang sebagai ketidakmampuan dari sisi ekonomi untuk memenuhi kebutuhan dasar makanan dan bukan makanan yang diukur dari sisi pengeluaran.

Kesejahteraan adalah hak semua orang, namun tidak semua orang mampu meraih kesejahteraan dalam kehidupannya. Ketidakmampuan tersebut disebabkan berbagai faktor baik yang ada dalam diri individu yang bersangkutan maupun faktor dari luar. Namun semua itu dapat diatasi sudah pasti harus dengan kemauan yang kuat dari penyandang masalah dan keuletan pekerja sosial dalam melaksanakan tugasnya. Pemerintah telah memberikan kemudahan dengan adanya regulasi yang jelas yang mampu melindungi dan memberikan kesempatan dengan berbagai program untuk kepentingan masyarakat yang memiliki keterbatasan. 
Pemerintah Provinsi Kalimantan Tengah melalui Panti Sosial Bina Remaja dan Karya Wanita (PSBRKW) Majar Tabela Palangka Raya Provinsi Kalimantan Tengah yang didukung dana APBD memberikan pelayanan dan rehabilitasi sosial dengan tujuan agar para penyandang masalah sosial remaja putus sekolah mampu melaksanakan fungsi sosial secara wajar setelah mendapatkan pelayanan sosial berupa bimbingan fisik, mental, sosial, dan latihan keterampilan. Keempat komponen bimbingan tersebut merupakan satu kesatuan yang utuh guna mempersiapkan remaja agar memiliki fisik yang sehat, mental yang mantap untuk bertahan pada nilai-nilai moral yang berlaku, mampu hidup bersama orang lain dengan komunikasi dan toleransi serta memiliki sikap setia kawan yang didukung dengan keterampilan yang memadai agar menjadi manusia yang produktif.

Adner (1998:12) mengemukakan tentang pengertian produktif yang memiliki keterampilan untuk suatu tingkat tertentu dan siap dikembangkan lebih lanjut sesuai dengan ekonomi dan teknologi yang terus berkembang. Carnevalu \& Porro - orang yang berpendidikan baik dan terampil berpeluang untuk tampil beda, bahkan dalam keadaan krisis ekonomi sekalipun mereka dapat terhindar dari kemiskinan dan pengangguran (Carnevale A.P. \& Porro, Quality, 1994: 52).

\section{Permasalahan}

Kalimantan Tengah adalah salah satu provinsi yang juga memiliki visi untuk memajukan masyarakatnya dengan memberikan kesempatan memperoleh pendidikan dan keterampilan yang layak serta pembinaan karakter yang kuat demi mewujudkan kesejahteraan dimaksud. Oleh karena itu perlu pembinaan dalam ranah konseling atau penyuluhan terhadap peserta didik yang bukan pada dunia formal untuk memiliki kemampuan lifeskills yang setara dengan peserta didik pada pendidikan formal di Kalimantan Tengah.

\section{Tujuan}

Tujuan kegiatan pengabdian kepada masyarakat ini adalah memberikan layanan konseling keterampilan hidup secara intensif kepada para peserta program melalui pelaksanaan kegiatan konseling keterampilan hidup pada program lifeskills di Panti Sosial Bina Remaja dan Karya Wanita (PSBRKW) Majar Tabela Palangka Raya Provinsi Kalimantan Tengah.

\section{METODE PELAKSANAAN}

\section{Waktu dan Tempat}

Kegiatan pengabdian kepada masyarakat dalam bentuk layanan konseling keterampilan hidup pada program lifeskills ini dilaksanakan dengan waktu pengabdian selama 12 sesi dalam satu semester pada tahun penerimaan. Pengabdian kepada masyarakat ini dilaksanakan di Panti Sosial Bina Remaja dan Karya Wanita (PSBRKW) Majar Tabela Palangka Raya Provinsi Kalimantan Tengah yang berlokasi di Jalan Rajawali Palangka Raya.

\section{Sasaran Kegiatan}

Masyarakat sasaran pada kegiatan pengabdian kepada masyarakat ini adalah para remaja peserta program lifeskills di Panti Sosial Bina Remaja dan Karya Wanita (PSBRKW) Majar Tabela Palangka Raya Provinsi Kalimantan Tengah. 


\section{Metode Kegiatan}

Metode yang diberikan pada kegiatan pengabdian kepada masyarakat ini berupa pembentukan lifeskills bagi para remaja adalah melalui pemberian layanan kepada peserta sehingga mampu memiliki ketahanan hidup setelah keluar dari PSBRKW tersebut. Proses pelayanan pada Panti Sosial Bina Remaja dan Karya Wanita (PSBRKW) Majar Tabela Palangka Raya Provinsi Kalimantan Tengah dilaksanakan selama 5 (lima) bulan dengan tahapan pelayanan sesuai dengan kaidah profesi pekerjaan sosial.

\section{Solusi yang Ditawarkan}

Pelaksanaan kegiatan ini secara intensif diberikan kepada para peserta program melalui pelaksanaan kegiatan konseling keterampilan hidup pada program lifeskills PSBRKW dalam pelaksanaan pendidikan kecakapan hidup program lifeskills di Provinsi Kalimantan Tengah dengan tahapan pelaksanaan sebagai meliputi : Tahap seleksi; Tahap registrasi, orientasi dan sosialisasi; Tahap bimbingan fisik, mental, sosial, dan latihan keterampilan; Tahap bimbingan fisik, mental, sosial dan latihan keterampilan; Tahap resosialisasi; dan Tahap bimbingan lanjut.

\section{HASIL DAN PEMBAHASAN}

Prosedur pelaksanaan program pendidikan lifeskills di Panti Sosial Bina Remaja dan Karya Wanita (PSBRKW) Majar Tabela Palangka Raya Provinsi Kalimantan Tengah ini dibagi dalam dua tahap yaitu dari petugas panti dan dari pemberi konseling keterampilan hidup melalui tahap-tahap yang sistematis sebagai berikut:
1. Prosedur Pelayanan

Pelayanan pada PSBRKW Majar Tabela Palangka Raya Provinsi Kalimantan Tengah dilaksanakan dengan prosedur sebagai berikut :

a. Motivasi dilaksanakan oleh petugas kabupaten/kota yang telah memiliki pemahaman terhadap sasaran melalui panduan seleksi yang dikirim oleh PSBRKW

b. Petugas Provinsi dalam hal ini petugas PSBRKW Majar Tabela Palangka Raya Provinsi Kalimantan Tengah melaksanakan seleksi bersama petugas kabupaten/kota.

c. Hasil seleksi yang telah dirumuskan oleh tim merupakan bahan untuk PSBRKW Majar Tabela Palangka Raya Provinsi Kalimantan Tengah melakukan panggilan terhadap calon klien di kabupaten/kota.

d. Petugas kabupaten/kota mendampingi kedatangan calon klien yang akan menerima pelayanan yang langsung dilakukan registrasi oleh PSBRKW Majar Tabela Palangka Raya Provinsi Kalimantan Tengah.

e. Pelaksanaan pelayanan yang berlangsung selama 5 (lima) bulan di PSBRKW

f. Setelah berakhirnya pelayanan dilakukan terminasi dengan mengembalikan klien kepada orang tua/wali mereka melalui dinas kabupaten/kota yang selanjutnya agar dilakukan pemantauan dan bimbingan lanjut. 
2. Proses Pelayanan

Proses pelayanan pada PSBRKW Majar Tabela Palangka Raya Provinsi Kalimantan Tengah dilaksanakan selama 5 (lima) bulan dengan tahapan pelayanan sesuai dengan kaidah profesi pekerjaan sosial yaitu sebagai berikut :

a. Pendekatan awal; identifikasi, motivasi dan seleksi.

Identifikasi dan motivasi dilaksanakan oleh petugas kabupaten/kota diharapkan calon klien telah memiliki minat sebelum seleksi dilaksanakan. Selanjutnya petugas provinsi dalam hal ini petugas PSBRKW bersama petugas kabupaten/kota melakukan seleksi agar didapatkan calon klien yang memenuhi persyaratan. Kegiatan ini dilaksanakan 1 (satu) tahun 2 (dua) kali atau setiap angkatan. Pelaksanaan kegiatan berlangsung pada bulan Januari dan Juni dalam 1 (satu) tahun.

b. Penerimaan; registrasi, pemahaman dan pengungkapan masalah serta penempatan dalam program pelayanan.

Calon klien diterima di PSBRKW pada bulan Februari dan angkatan II pada bulan Juli. Saat kedatangan calon klien diterima dan dilakukan registrasi.

Pada saat yang bersamaan petugas memeriksa barang yang dibawa calon klien, jika terdapat barang berharga maka barang tersebut disimpan oleh pendamping dalam hal ini pekerja sosial. Pemahaman dan pengungkapan masalah (asesmen) dilakukan selama 1 minggu pertama untuk melihat ketepatan penempatan klien dalam program pelayanan. Disamping itu masa 1 minggu pertama juga dilakukan observasi dan orientasi terhadap kehidupan di PSBRKW

3. Proses Pendidikan Lifeskills PSBRKW Majar Tabela Palangka Raya Provinsi Kalimantan Tengah

a. Tahap seleksi

Identifikasi dan motivasi dilaksanakan oleh petugas kabupaten/kota diharapkan calon klien telah memiliki minat sebelum seleksi dilaksanakan. Selanjutnya petugas provinsi dalam hal ini petugas PSBRKW bersama petugas kabupaten/kota melakukan seleksi agar didapatkan calon klien yang memenuhi persyaratan. Kegiatan ini dilaksanakan 1 (satu) tahun 2 (dua) kali atau setiap angkatan. Pelaksanaan kegiatan berlangsung pada bulan Januari dan Juni dalam 1 (satu) tahun.

b. Tahap registrasi, orientasi dan sosialisasi Calon klien diterima di PSBRKW pada bulan Februari dan angkatan II pada bulan Juli. Saat kedatangan calon klien diterima dan dilakukan registrasi. Pada saat yang bersamaan petugas memeriksa barang yang dibawa calon klien, jika terdapat barang berharga maka barang tersebut disumpan oleh pendamping dalam hal ini pekerja sosial. Pemahaman dan pengungkapan masalah (asesmen) dilakukan selama 1 minggu pertama untuk melihat ketepatan penempatan klien dalam program pelayanan. Disamping itu masa 1 minggu pertama 
juga dilakukan observasi dan orientasi terhadap kehidupan di PSBRKW.

c. Tahap bimbingan fisik, mental, sosial dan latihan keterampilan

Bimbingan fisik dan mental meliputi Peraturan Baris Berbaris (PBB) dengan instruktur dari Korem 102 Panju Panjung. Disamping itu kegiatan outbound dilakukan dalam rangka pengembangan kapasitas pribadi. Bimbingan spiritual diberikan meliputi bimbingan keagamaan termasuk akhlak melalui pengajian, kultum, dzikir dan kebaktian serta pemahaman terhadap Al-Kitab).

Bimbingan sosial diberikan meliputi bagaimana klien melakukan hubungan bermasyarakat antara klien dengan petugas, dengan orang tua asuh/asrama, dan dengan lingkungan di sekitar PSBRKW. Menunjang kemampuankemampuan diatas dibarengi dengan latihan keterampilan sesuai dengan jenis keterampilan yang diminati oleh masingmasing klien.

Dalam pelaksanaan pelayanan baik di PSBRKW tidak terdapat kendala yang cukup berarti. Pengalaman dan etos kerja yang baik serta jiwa keterpanggilan dalam melaksanakan tugas menjadikan kesulitan-kesulitan kerja dapat disikapi secara positif. Para petugas memiliki komitmen bahwa yang utama adalah memberikan hak-hak yang wajar kepada penerima pelayanan/klien sesuai dengan kemampuan lembaga yang memliputi seluruh aspek pelayanan.
Permasalahan klien dengan kebiasaankebiasaan yang bertentangan dengan sikap positif dalam melihat kehidupan seperti mereka tidak terlalu mengenal disiplin, memiliki kebiasaan merokok bahkan sebagian terbiasa dengan minuman keras, kebersihan yang kurang diperhatikan dinilai sebagai tantangan bagi pekerja sosial dan petugas lainnya.

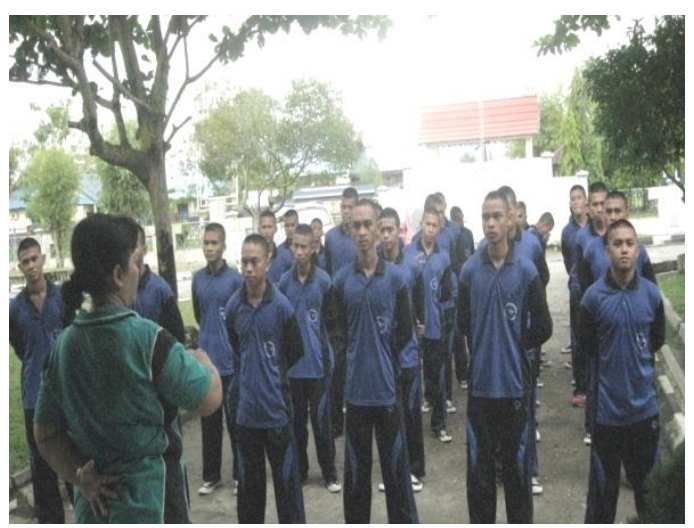

Gambar 1. Pesera Program sedang Bimbingan Fisik pada hari Minggu pagi

d. Tahap resosialisasi

Resosialisasi atau proses kembali kepada lingkungan sosial klien. Dilakukan bimbingan kesiapan dan peran serta masyarakat, bimbingan sosial hidup bermasyarakat, bimbingan bantuan stimulan usaha produktif, renungan untuk memantapkan kemampuan-kemampuan yang telah dimiliki serta bimbingan penyaluran/penempatan kerja. Kegiatan ini berlangsung mendekati hari kepulangan klien.

e. Tahap bimbingan lanjut Klien yang telah menyelesaikan waktun pembinaan di PSBRKW selama 5 (lima) bulan selanjutnya kembali ke masyarakat/ke orang tua atau bekerja 
langsung ditempat magang. Kegiatan ini dilakukan dengan upaya bimbingan lanjut yang dilaksanakan oleh petugas PSBRKW bersama petugas dinas kabupaten/kota. Selain itu bimbingan lanjut dilakukan dalam rangka mendapatkan data dan informasi perkembangan eks penerima program. Selain itu data dan informasi hasil bimbingan lanjut diakomodir dan ditindaklanjuti untuk kepentingan peserta program. Dalam program ini, pengabdian difokuskan pada proses konseling keterampilan hidup yang mengacu pada 4 bentuk bimbingan yaitu bimbingan sosial, bimbingan keterampilan, bimbingan mental, dan bimbingan fisik.

Proses layanan konseling keterampilan hidup berangkat dari asumsi-asumsi dalam bimbingan dan konseling terpolakan dalam beberapa hal berikut;

1. Asumsi-Asumsi Konseling Keterampilan Hidup

Teori keterampilan hidup berupaya memenuhi ketiga fungsi utama teori konseling (Nelson-Jones 1995: 414), Pertama, mempersiapkan kerangka kerja konseptual yang memungkinkan konselor memikirkan perkembangan manusia dan praktek konseling. Kedua, memberikan bahasa atau perbendaharaan bahasa yang dapat digunakan untuk percakapan konseling, Ketiga, KKH dapat dipandang sebagai suatu seri hipotesis penelitian. Misalnya, melakukan penelitian tentang proses-proses dan hasil-hasil yang dicapai konselor maupun klien dengan menggunakan bahasa keterampilan dan hasil-hasilnya setelah selesai konseling dengan tujuan memelihara keterampilan menolong diri.

Nelson-Jones mengemukakan bahwa teori konseling mempunyai empat elemen, yaitu (a) pernyataan tentang asumsi asumsi yang dasar yang melandasi teori; (b) eksplanasi tentang peralihan perilaku yang bias dibantu dan yang tidak; (c) eksplanasi tentang pemeliharaan perilaku-perilaku tersebut, dan (d) eksplanasi tentang cara membantu klien mengubah perilakunya dan mengkonsulidasi hasil-hasil perubahan pada akhir konseling. Secara rinci konsep tersebut dapat dipahami sebagai berikut:

a. Kehidupan biologis dan spikologis. Perhatian utama $\mathrm{KKH}$ lebih kepada kehidupan spikologis dari pada kepada kehidupan biologis. Kedua konsep ini saling tumpang tindih dan dapat saling mempengaruhi. Keberadaan kehidupan spikologis berperan kehidupan biologis.

b. konseling keterampilan hidup menggunakan bahasa keterampilan, yaitu penggunaan yanbg konsisten konsepkonsep keterampilan untuk menggambarkan dan menganalis perilaku manusia.

c. Manusia mempunyai tiga bentuk self pertama, "natural self" menggabungkan karakteristik seperti energi, seksualitas, perasaan dan kecemasan. Sifatnya unik dan merupakan inti biologis manusia, kedua, self yang dipelajari merupakan hasil pengalaman belajar. Ketiga, self 
eksekutif merupakan kapasitas untuk saat sekarang dan masa mendatang. Jadi manusia tidak hanya mempunyai menciptakan self baru

d. Semua orang mempunyai penguatan dorongan ke arah pertahanan hidup, pemeliharaan dan pengembangan diri. Akibatnya, manusia dapat memperoleh pengalaman yang baik atau tidak baik dalam memperoleh dan mempelajari cara-cara memelihara dan mengembangkan keterampilanketerampilan hidup.

e. Bahwa kecemasan mempunyai makna positif dan negative. Kecemasan itu ada dua macam, yaitu kecemasan survival yang bias bersifat sadar, prasadar dan tidak sadar. Pada berbagai tingkatan manusia peristiwa kecemasan pra sadar dapat timbul dalam situasi yang relative tidak berbahaya, misalnya pada konseling atau pergaulan yang menyenagkan. Sedangkan kecemasan yang tidak disadari adalah kecemasan yang ditekan karena terlalu menakutkan bagi individu yang bersangkutan. Kecemasan yang tidak disadari biasanya muncul dalam bentuk mimpi buruk.

f. Tanggungjawab pribadi merupakan sesuatu konsep yang sulit diamati. KKH mengambil pandangan eksistensial tentang manusia sebangai penanggungjawab bagi penguasa hidupnya maupun sebagai penemu atau pencipta hidupnya. Tanggungjawab pribadi merupakan "inner process" dimana manusia bertindak "dari dalam ke luar", proses ini aturan-aturan ke arah tindakan yang dapat diamati.

g. Setiap manuisa mempunyai keberanian. Menurut Nelson Jones (1997: 21) keberanian dapat dikelompokan menjadi tiga kelompok, walupun saling tumpang tindih. Pertama, keberanian untuk melawan atau menyerah kepada kelemahan-kelemahan keterampilan hidup. Kedua, keberanian untuk mengembangkan kekuatan-kekuatan keterampilan hidup. Pengembangan kekuatan-kekuatan keterampilan hidup seringkali dipengaruhi oleh faktor-faktor yang tidak dapat dihindari yang menyebabkan kesulitan pelaksanaannya. Faktor-faktor tersebut meliputi kegiatankegiatan yang berkaitan dengan belajar dan penguahan keterampilan hidup serta kecemasan. Ketiga, keberanian untuk memelihara dan mengembangkan keterampilan hidup.

2. Tujuan Konseling Keterampilan Hidup Konseling keterampilan hidup berusaha membantu klien memperoleh kekuatan dan menghilangkan kelemahan keterampilan berpikir dan bertindak; dan memperoleh pemahaman tentang bahasa keterampilan, yaitu kecakapan memikirkan dan menganalisis perilakunya dalam bentuk keterampilan.

Keterampilan berpikir (inner games of livinga) menunjuk kepada apa yang sedang terjadi dalam diri seseorang yaitu yang dipikirkannya, sifatnya tertutup (covert). Keterampilan bertindak (outer games of living) menunjukan kepada apa yang sedang 
berlangsung di luar diri seseorang, yaitu apa yang dilakukan dan sifatnya terbuka. Manusia perlu untuk dapat menagalami, menyatakan dan mengelola perasaan yaitu hakekat hewani manusia dan tidak memgundang keterampilan.

3. Terbentuknya Kekuatan dan Kelemahan Hidup

Kekuatan-kekuatan dan kelemahankelemahan keterampilan berpikir dan bertindak diperoleh melalui bebrapa proses (Nelson-Jones; 1995:427-431) seperti :

a. Hubungan suportif. Jenis hubungan ini dapat dipenuhi oleh banyak selain orang tua, termasuk nereka yang merupakan figure yang menyenangkan, dapat diharapkan, atau dipercayai.

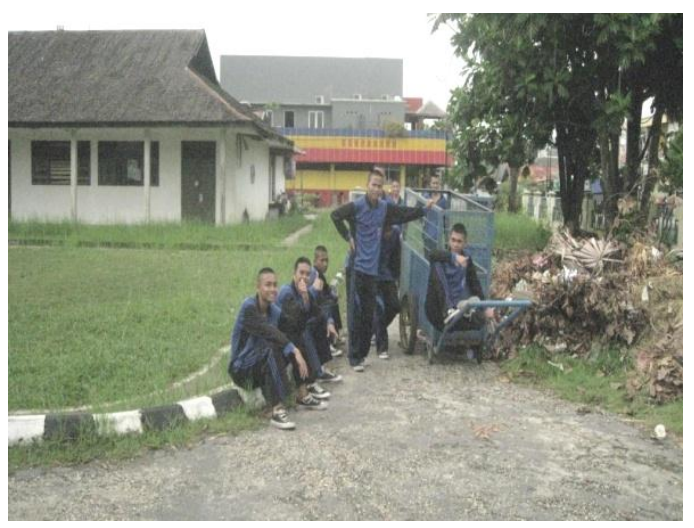

Gambar 2. Membangun hubungan positif antar peserta program lifeskills

b. Belajar dari contoh. Cara ini merupakan cara yang utama dalam memperoleh kekuatan dan kelemahan keterampilan hidup ( Bandura dalam Nelson-Jones, 1995; 428); mereka yang dijadikan contoh adalah orang tua dan orang-orang yang berarti (significant others) termasuk ke dalam kelompok ini adalah teman sebaya, guru, teman lain dan bahkan media masa..

c. pengajaran dan pembelajaran diri (selfinstruction). Manusia mempunyai kemampuan berpikir sembolis dan kemampuan melakukan komunikasi, maka pengajaran merupakan suatu lembaga penyampaian kekuatan dan kelemahan keterampilan hidup. Rumah dan persahabatan maupun kelompok sebaya, menenamkan keterampilan hidup yang dasar. secara memadai keterampilan yang harus dipelajari setelah kegiatan pengajaran.

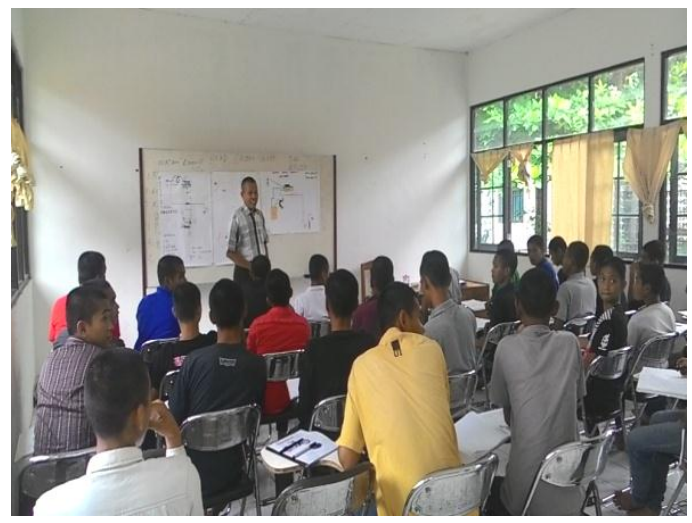

Gambar 3. Membangun kepercayaan diri dalam pembelajaran dan pengajaran

d. Informasi dan kesempatan. Pengembangan ketarampilan hidup, sangat memerlukan informasi yang memadai. Penyampaian informasi yang tidak lengkap dan didasari kebohongan, melanggar kebenaran dan memecahmecah kebenaran harus dihindari, karena akan menghambat perkembangan kesadaran diri dan sifat responsive emosional. Informasi yang penting tidak selalu siap didapat di luar rumah, 
misalnya informasi tentang karir. Perlu diingat bahwa kebutuhan memperoleh kesempatan untuk mencoba dan mengembangkan keterampilan hidup diperlukan oleh anak-anak, remaja maupun orang dewasa, namun kesempatan tersebut sebaiknya diberikan sesuai kematangan dan kesiapan. Materi kesempatan dibedakan oleh jender, ras, budaya, kelas social, posisi financial dan pendidikan, serta keterbukaan orang tua. Karena itu diakui bahwa sebenarnya anak dan orang dewasa mempunyai peran dalam mencari informasi dan kesempatan.

e. Kecemasan dan percaya diri.

Perkembangan mengandung pengalaman yang membantu dan merusak perkembangan penghargaan diri (selfesteem). Anak yang beruntung memperoleh tingkat kecemasan yang melindungi bahaya-bahaya actual dan mendorong kearah pencapaian tujuan yang realitas. Mereka yang kurang beruntung dapat memperoleh pengurangan kecemasan melalui peran model, pangajaran, dan memberikan langkah-langkah persiapan menerima konsekuensi kegagalan.

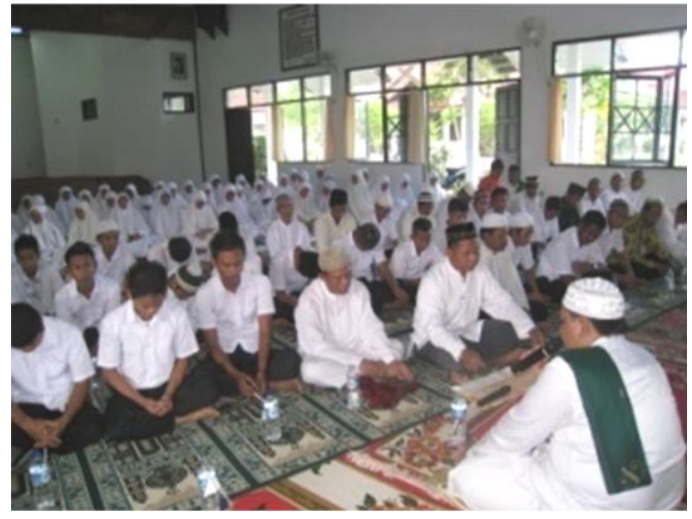

Gambar 4. Pembinaan Rohani Peserta Program Lifeskills

\section{SIMPULAN DAN SARAN}

\section{Simpulan}

Pelaksanaan layanan konseling keterampilan hidup sejatinya memberikan dampak kuat pada proses penjangkaran bagi peserta yag mengikuti program ini sehingga peserta memiliki kemampuan memahami nilai-nilai afektif yang sangat berguna pada kehidupan mereka setelah keluar dari program ini yaitu; kemampuan memahami diri sendiri.

Selain itu peserta program memiliki kemampuan memahami orang lain. Hal ini dapat terlihat dengan kemapuan empatinya terhadap orang lain. Kemampuan berempati artinya kesadaran terhadap perasaan, kebutuhan, dan kepentingan orang lain yang meliputi beberapa aspek, yaitu : pertama, memahami orang lain; kedua, mampu mengantisipasi, mengenali, dan berusaha memenuhi kebutuhan teman-teman sekitarnya; ketiga, mampu merasakan kebutuhan perkembangan orang lain dan berusaha menumbuhkan kemampuan mereka; keempat, mampu menumbuhkan peluang melalui pergaulan dengan bermacam-macam orang dan mampu mengatasi masalah perbedaan. 


\section{Saran}

Pengabdian kepada masyarakat dalam bentuk seperti ini seharusnya mendapat perhatian yang serius dari seluruh pihak untuk melanjutkan program layanan konseling keterampilan hidup pada ranah lifeskills bagi peserta selanjutnya.

\section{UCAPAN TERIMA KASIH}

Ucapan terima kasih disampaikan kepada Universitas Muhammadiyah Palangkaraya yang telah memfasilitasi dan membantu pendanaan pembiayaan kegiatan pengabdian kepada masyarakat ini. Terimakasih juga disampaikan kepada pihak Panti Sosial Bina Remaja dan Karya Wanita (PSBRKW) "Majar Tabela" Palangka Raya Provinsi Kalimantan Tengah dan remaja peserta program lifeskills yang yang secara aktif berpartisipasi pada kegiatan pengabdian kepada masyarakat ini.

\section{DAFTAR PUSTAKA}

Adner M.J. 1998. The Paidea Proposal: an Educational Manifesto, (new York : Coller)

Carnevale A.P. \& Porro, 1994. Quality Education, (Washington D.C.: School Reform for the New American Economy)

Cohn, Elchanan. 1979. The Economics of Education. (Massachusetts Balinger Publishing Company)

John W. Santrock. 2009. Psikologi Pendidikan (Buku 1 Edisi 3). Jakarta : Salemba Humanika.

Petter H. Rossi and Howard E. Freeman. 1993. Evaluation a Systematic Approach. California : Sage Publication)

Rencana Strategis Kementerian Pendidikan Nasional R.I. Tahun 2010-2014.
Soedijarto. 2011. Undang-Undang Nomor 20 Tahun 2003 tentang Sistem Pendidikan Nasional : Makna dan Dampaknya terhadap Penyelenggaraan Pendidikan (Sebuah Tinjauan Kritis). Makalah pada Seminar Nasional yang diselenggarakan Asosiasi Badan Penyelenggaraan Perguruan Tinggi Swasta Indonesia. 